\title{
POLSKA MIGRACJA: MOTYWY MOBILNOŚCI, JEJ DYNAMIKA I PROPOZYCJA SOCJOLOGICZNEJ REKONCEPTUALIZACJI
}

By zilustrować dynamikę migracyjną okresu po roku 1989, najlepiej prześledzić dwa typy czynników, obecne w tradycyjnej teorii migracji: 1) „czynniki wypychajace" (ang. push factors) lub indywidualne, które tworzyły strukturalny kontekst dynamiki społecznej, oraz 2) ,czynniki przyciagające” (ang. pull factors) lub indywidualne (zgodnie z przyjętym w artykule nazewnictwem) decydujące wprost o podjęciu decyzji migracyjnej ${ }^{1}$. Obydwa typy poddam własnej konceptualizacji, inspirując się materiałem badawczym zamieszczonym w pracy (Post) transformational Migration. Inequality, Welfare State, and Horizontal Mobility ${ }^{2}$ oraz m.in. danymi z badań statystycznych i badań opinii publicznej publikowanych w innych opracowaniach, w tym w książce autorstwa Izabeli Grabowskiej-Lusińskiej i Marka Okólskiego Emigracja ostatnia? ${ }^{3}$ oraz pracy zbiorowej Zróżnicowania warunków życia. Polskie rodziny i społeczności lokalne $e^{4}$.

$\mathrm{W}$ analizie tytułowego zagadnienia posługuję się konstruktem teoretycznym, który każe poszukiwać dynamiki migracyjnej w procesach gospodarczych, precyzyjnie zaś - głównie w uwarunkowaniach rynku pracy. Nie akceptuję jednak ekonomistycznej perspektywy samoregulującego się rynku czy migracji pojmowanej jako „zawór bezpieczeństwa” gospodarki bądź jako likwidacja „nawisu” siły roboczej5.

${ }^{1} \mathrm{~W}$ niniejszym opracowaniu posługuję się pojęciami zaczerpniętymi od jednego z najstarszych teoretyków tego zagadnienia: Ernesta Revensteina. Ten autor wprowadził do teorii migracyjnej pojęcia opisujące czynniki wypychające (ang. push factors) oraz czynniki przyciagające (pull factors). Obydwa pojęcia w naukach geograficznych służą do opisania dynamiki przemieszczania się ludności w przestrzeni, w przypadku opracowania, na które się powołuję, służą do tego modele matematyczne dające podstawy do rekonstrukcji zjawisk migracyjnych na terenie Stanów Zjednoczonych. Czynniki wypychające to zatem te „sytuacje życiowe, które powoduja brak satysfakcji z dotychczasowej lokalizacji przestrzennej”. Czynniki przyciagające dotyczą „tych atrybutów odległych miejsc, które zdają się pociagające" z punktu widzenia decyzji o zmianie miejsca (por. G. Dorio, W. Cobler, Push-Pull Migration Laws, „Annals of the Association of American Geographers" 73, 1983, nr 1).

${ }^{2}$ M. Nowak, M. Nowosielski (red.), (Post)transformational Migration. Inequalities, Welfare State, and Horizontal Mobility, Peter Lang, Frankfurt am Main 2011.

${ }^{3}$ I. Grabowska-Lusińsk, M. Okólski, Emigracja ostatnia?, Scholar, Warszawa 2009.

${ }^{4}$ K. Zagórski, G. Gorzelak, B. Jałowiecki (red.), Zróżnicowania warunków życia. Polskie rodziny i społeczności lokalne, Scholar, Warszawa 2009.

${ }^{5}$ Przyjmowana perspektywa jest w opozycji do zaproponowanych interpretacji: socjologiczna, o tyle wszakże, o ile masowa emigracja postrzegana jest jako wskaźnik kondycji społecznej, a precyzyjniej - zjawiska anomii społecznej. Polemizuję w tym miejscu ze stanowiskiem Marka Okólskiego (por. I. Grabowska-Lusińska, M. Okólski, op. cit., s. 15). 


\section{KONCEPTUALIZACJA PROBLEMATYKI MIGRACYJNEJ}

Tematyka migracyjna zyskała zdecydowanie na znaczeniu wraz z największa jak dotąd falą emigracji (uwzględniając te współczesne i np. niezwiązane z działaniami wojennymi), jaka nastapiła po akcesji Polski do struktur Unii Europejskiej w 2004 r. Ten wzrost zainteresowania nie wynikał jednak z zaskakującego zaistnienia zjawiska. Raczej z powszechnego dostrzeżenia jego dużej skali i dynamiki nabierającej czasami kształtu exodusu, swoistej paniki, którą da się porównać jedynie z atmosfera towarzyszącą fali wyjazdów z lat osiemdziesiątych XX w. Ta wcześniejsza emigracja miała jednak inny charakter, była nieco mniej liczna, wzmacniana atmosfera delegitymizacji władzy realnego socjalizmu u schyłku tego systemu. Była również wewnętrznie silnie zróżnicowana. Spora grupę wśród ogółu emigrantów stanowiły osoby powołujące się na korzenie niemieckie (niem. Spätaussiedler), co sugeruje również kryzys tożsamości obok uwarunkowań czysto ekonomicznych. Badacze szacują emigrację tego okresu na ok. 800 tys. ludzi, choć szacunki bardzo się różnią. Podobnie zresztą zróżnicowane były drogi i strategie opuszczania kraju. Liczna grupa emigrantów stała się po prostu „niewidzialna” - znikali oni, korzystając z dobrodziejstw uzyskanej, nie bez trudu, wizy turystycznej ${ }^{6}$.

Kolejna fala emigracji nastapiła w latach dziewięćdziesiątych XX w. W latach 1989-2001 na podstawie danych Głównego Urzędu Statystycznego szacowno ją na ok. 293 tys. osób ${ }^{7}$. Ten okres charakteryzował się również znacznym natężeniem wyjazdów wahadłowych, na krótszy bądź dłuższy czas, na podstawie łatwiej już dostępnej wizy turystycznej. Jeśli zastosować nieco bardziej elastyczne kryteria definiowania emigracji (przypomnę standardowo, że zgodnie z ustaleniami Eurostatu jest to ponadroczny pobyt za granica), ta liczba powinna ulec zdecydowanemu powiększeniu. Co warto podkreślić, migracja lat dziewięćdziesiątych XX w. skierowana była bezpośrednio na zachód i na południe (dominowały Niemcy i Austria) i związana była bardzo często z nielegalnymi lub półlegalnymi formami zatrudnienia, a jej oszacowanie utrudniał brak form rejestracji (osób, które wyjechały i podjęły pracę) zarówno w Polsce, jak i poza granicami kraju.

Kolejna, bliższa nam czasowo emigracja - nazywam ją now ą e migracja (po 20 i więcej latach od pierwszych nie do końca jeszcze demokratycznych wyborów w 1989 r.) - była znacznie mniej polityczna (lub świadoma swojej polityczności), choć próbowano nadać jej charakter sprzeciwu wobec konserwatywnych rządów połowy pierwszego dziesięciolecia XXI w. ${ }^{8}$ Jej cele były, podobnie jak w przypadku fal z lat dziewięćdziesiątych XX w., zorientowane na czynniki wypychające (ang. push factors): poziom dochodów i różnice w sile nabywczej euro, funta i złotówki itp.

Nieco inaczej wydaje się, że jest z najnowszą falą emigracji - nazwę ją kryzysową - która stanowiła (a zapewne również stanowi) bardziej odpo-

${ }^{6}$ Por. I. Grabowska-Lusińska, M. Okólski, op. cit., s. 11.

${ }^{7}$ Ibidem, s. 53.

${ }^{8}$ Które przyniosły wyniki wyborów z 2005 r. oddające władzę w ręce środowisk postsolidarnościowych (PiS) oraz ich egzotycznych koalicjantów (LPR i „Samoobrona”). 
wiedź na uwarunkowania zewnętrzne niż wewnętrzne (kryzys ekonomiczny, którego początek ustala się z reguły na 2007 lub 2008 r.). Ilustruje jednocześnie przesunięcie motywów emigracji z „wewnętrznych” (przywołane push factors) w kierunku czynników „przyciagających” (ang. pull factors) teorii migracji, co oznacza bardziej refleksyjną rekapitulację ocen potencjału rozwojowego w odmiennych społeczeństwach europejskich i oceny potencjałów poszczególnych rynków pracy 9 .

Obydwie najbardziej współczesne fale migracji („nowa” i „kryzysowa”), nieodmienne, jak się wydaje w kwestii ekonomicznych motywów, zdecydowanie różni od wcześniejszych atmosfera wokół ładu społecznego i reguł, które rządzą gospodarką. Polacy od połowy pierwszego dziesięciolecia nowego millenium zdecydowanie zaakceptowali reguły rynkowe (o czym będzie jeszcze mowa). Dynamikę zjawiska emigracji da się w związku z tym wyjaśniać pozytywnym sprzężeniem zwrotnym wynikającym czy to z utrzymywania się na względnie stałym, wysokim poziomie nierówności społecznych ${ }^{10}$ (jako czynnika motywującego do mobilności), czy to krytycznej oceny własnej siły nabywczej na porównawczym tle ${ }^{11}$. Warto nadmienić, że coraz powszechniejsze urynkowienie strategii życiowych nie dotyczyło jednak bardziej całościowych postaw i zachowań w ramach polskiej gospodarki, czego symptomem mogłyby być wzrost migracji i dynamiczniejsze przemieszczenia na osi wieś-miasto czy miasta peryferyjne - regionalne metropolie. Strategia mobilności międzynarodowej (emigracji) wynikała zatem raczej z niemożności osiagania indywidualnych celów na poziomie wspólnoty przestrzennej, zarówno gdy postrzegamy ja lokalnie, jak i regionalnie. Była swego rodzaju „anomicznym” substytutem mobilności wewnątrz wspólnoty. Wniosek taki uprawdopodobniają badania deklaracji dotyczących zmiany miejsca zamieszkania systematycznie rejestrowane choćby przez CBOS $^{12}$. Stawiajacc rzecz wprost, relatywnie niskiego poziomu takiej deklarowanej mobilności.

Odpowiadajac zatem na narzucające się pytanie, czy Polacy są mobilni, odpowiemy, że generalnie w niewielkim stopniu. Wskazana niespójność

${ }^{9}$ Szczególny status celów emigracji uzyskują częściej te, którym udało się uniknać zapaści na wewnętrznym rynku pracy i jednocześnie utrzymują relatywnie wysoki poziom akceptacji dla migrantów.

${ }^{10}$ Wertykalnie wyznaczone np. poziomem współczynnika Giniego dla całego kraju, oraz horyzontalnie w układzie przestrzennym: regionalnym; ze względu na ulokowanie i specyfikę gmin; „dyspersję” wielkich centrów miejskich (silnie różnicując potencjały rozwojowe i samorealizacyjne); dalej, osłabienie potencjału rozwojowego małych i średnich miast oraz kolei losów terenów niezurbanizowanych często borykających się ze strukturalnym bezrobociem. Miara tych zróżnicowań/nierówności może być dystrybucja wskaźników poziomu życia lub analizy postrzegania nierówności dochodowych i sprawiedliwej ich dystrybucji (por. M. Nowak, Inequalities and Migration in Central and Eastern Europe, w: I. I. Eliseewa et al. (red.), Socjalnoje nierawienstwo w postsocjalisticzeskich stranach Centralnoj i Wostocznoj Jewropy: Socjologiczeskij analiz, Moskwa 2011.

${ }^{11}$ Nieakceptacją różnic pomiędzy tym, ile zarabiają inni, a ile moim zdaniem powinni zarabiać. Por. H. Domański, Sprawiedliwe nierówności zarobków, Scholar, Warszawa 2013.

${ }^{12}$ Warto przywołać wnioski choćby z dwóch raportów - z 1995 r.: „Ruchliwość zawodowa i geograficzna” (BS/74/61/95) oraz wnioski ze współczesnego badania z 2010 r.: „Mobilność i preferencje migracyjne Polaków" (BS/26/2010). 
wydaje się, że ma podstawowe znaczenia wskaźnikowe uzasadniające socjologiczne wyjaśnienia zjawiska emigracji (w opozycji do ich ekonomicznych odpowiedników).

\section{POLSKA MIGRACJA Z PERSPEKTYWY BADAWCZEJ}

Należy w tym miejscu wskazać na co najmniej trzy różniace się społecznie typy migracji, zależnie od czasu przebywania za granica, zakładając, że okres przebywania poza krajem ma tutaj znaczenie ze względu na społeczne konsekwencje zjawisk migracyjnych. Długość przebywania za granica mogłaby tu być wskaźnikiem „odrywania się” migranta od lokalnego kontekstu społecznego kraju pochodzenia; dotyczy nie tylko gospodarki lokalnej, lecz także konsekwencji mikrospołecznych wyjazdu dla życia rodzinnego, sieci relacji społecznych, społeczności lokalnej jako ciała politycznego itd.

Byłyby to, zgodnie z interpretacjami Grabowskiej-Lusińskiej i Okólskiego: migracja cyrkulacyjna (,cyrkulacja”), oznaczająca krótkotrwałe wyjazdy nieprzekraczajace trzech miesięcy (typowe, jak mniemam, dla prac sezonowych); migracja krótkookresowa (czyli taka, która nie przekracza jednego roku) oraz migracja długookresowa lub osiedleńcza (emigracja) trwająca więcej niż 12 miesięcy ${ }^{13}$. Krystyna Iglicka, patrząc na migracje niejako z drugiej strony, posługuje się w tym kontekście pojęciem „diaspory”, w rozumieniu George'a Brubakera, wskazując na ekonomiczny i polityczny sens „,społeczeństw migracyjnych" i rozmieszczonych w ich ramach odrębnych enklaw etnicznych i narodowych. Kraje Europy Zachodniej w coraz większym zakresie uzyskują właśnie taki charakter, co stanowi (niezależnie od tego, czy taka jest intencja lokalnej polityki migracyjnej) „przeniesienie” uwarunkowań społeczno-ekonomicznych z krajów, z których się emigruje, do krajów celu migracji ${ }^{14}$.

Jako przykład poczynionych ustaleń przywołam element analizy poświęconej migracji sezonowej, przeciwstawiając ją formie wyjazdów „nowej” migracji ukierunkowanej na Wielką Brytanię i Irlandię, a zatem migracji, która w opozycji do formuły bardziej rozpowszechnionej w latach dziewięćdziesiątych XX w. ma szanse uzyskać kształt diaspory.

$\mathrm{Na}$ podstawie opublikowanych danych np. pracownicy sezonowi (czyli „najsłabsza” forma mobilności międzynarodowej) są nieco starsi od emigrantów krótkookresowych, są również nieco gorzej wykształceni (dominuje wykształcenie zasadnicze zawodowe). W przypadku krótkotrwałych migrantów dominuje wykształcenie średnie, pojawia się również znacząca grupa osób z wykształceniem wyższym $(15 \%)^{15}$. Skłonność do pracy sezonowej jest rów-

\footnotetext{
${ }^{13}$ I. Grabowska-Lusińska, M. Okólski, op. cit., s. 38 i n.

${ }_{14}$ Por. K. Iglicka, Zarzqdzanie emigracja - wyzwania dla polskiej, polityki zagranicznej $i$ gospodarczej, Centrum Stosunków Międzynarodowych, „Raporty i Analizy” 1/10. Pełny opis stanowiska autorki można znaleźć w pracy: K. Iglicka, Powroty Polaków w okresie kryzysu gospodarczego. W pętli pułapki migracji, Scholar, Warszawa 2010.

${ }^{15}$ I. Grabowska-Lusińska, M. Okólski, op. cit., s. 47-49.
} 
nież bardziej przestrzennie skoncentrowana, zdecydowanie dotyczy np. Opolszczyzny oraz wybranych powiatów w istotnej części przygranicznych (nie chodzi jednak, co ciekawe, tylko o zachodnia granicę naszego kraju). W ramach migracji krótkookresowych dominują mężczyźni, kobiety sa jednak nieco lepiej wykształcone (co skądinąd odpowiada różnicom w zakresie wykształcenia typowym dla polskiej populacji).

Na podstawie badań zrealizowanych w drugiej połowie pierwszego dziesięciolecia XXI w.:

w Wielkiej Brytanii [były] to przede wszystkim osoby młode (90\% z nich ma mniej niż 35 lat), wykształcone (mniej niż 10\% posiada wykształcenie niższe niż średnie) i stanu wolnego (blisko 2/3 to osoby samotne bądź żyjące w konkubinacie). 3/4 z nich przebywa w Wielkiej Brytanii nie dłużej niż 2 lata (licząc od momentu realizacji badania), a więc swój pobyt na Wyspach rozpoczęło dopiero po wstapieniu Polski do Unii Europejskiej ${ }^{16}$.

\section{III. „CZYNNIKI WYPYCHAJĄCE” (STRUKTURALNE)}

Jednym z głównych „czynników wypychających” może być poziom bezrobocia, na co wskazuje koincydencja czasowa danych dotyczących wysokości bezrobocia i rejestrowanych fal migracji. Badanie CBOS-u, które w 2009 r. podjęło próbę bilansu 20 lat od wprowadzenia reguł rynkowych w Polsce, na pierwszym miejscu negatywnych konsekwencji transformacji odnotowało bezrobocie z 59\% odpowiedzi twierdzacych w roku 1999 i 33\% w $2009^{17}$. Nasuwa się oczywiście pytanie, czy da się dowieść związu pomiędzy tym parametrem makroekonomicznym (poziomem bezrobocia) a decyzjami o wyjeździe $\mathrm{z}$ kraju. Takich danych wprost nie ma i jest to zrozumiałe na gruncie metodologicznym, a ściślej, wynika ze strategii pozyskiwania danych statystycznych. Ci bowiem, którzy wyjechali, nie mogli odpowiadać na pytania agencji badania opinii publicznej w kraju (np. CBOS - posługuje się próbami losowymi opartymi na numerach PESEL i odnosi się do miejsc stałego zameldowania obywateli) $^{18}$.

Na podstawie prostej koincydencji zdarzeń da się jednak dostrzec, że bezrobocie było szczególnie intensywnie doświadczane właśnie w okresie poprzedzającym największą falę migracji ${ }^{19}$, która inaczej niż w przypadku zjawisk

${ }^{16}$ M. Milewski, J. Ruszczak-Żbikowska, Motywacje do wyjazdu, praca, więzi społeczne i plany na przyszłość polskich migrantów przebywajacych w Wielkiej Brytanii i Irlandii, CMR Working Papers 35/93, s. 8.

${ }^{17}$ Na podstawie odpowiedzi na pytanie: „Czy i co, pana(i) zdaniem, zmieniło się w tym czasie w Polsce na gorsze?". Por. K. Kuźmicz, Bilans zmian w Polsce w latach 1989-2009. Komunikat $z$ badań, BS/32/2009, Warszawa 2009 (http://www.cbos.pl/SPISKOM.POL/2009/K_032_09.PDF).

${ }^{18}$ By dotrzeć do interesujących danych, pozostaje pytać migrantów o ich motywy wyjazdu w kraju docelowym lub rozmawiać z powracającymi czasowo czy na stałe z emigracji. Tak czy inaczej wymaga to uruchamiania wyspecjalizowanych projektów badawczych w krajach, do których Polacy emigruja, co wymaga wysiłku zarówno metodologicznego (kwestii, jak docierać do migrantów i jak ich badać), jak i stworzenia instytucjonalnych warunków do takich projektów badawczych. Problemem tym zajmę się w podsumowującej części artykułu.

${ }_{19}$ Przypomnijmy, że poziom bezrobocia w okresie poprzedzajacym polską akcesję do struktur UE przekroczył granicę bezpieczeństwa społecznego, za jaką uznaje się poziom $20 \%$ siły roboczej 
z lat dziewięćdziesiątych nie dotyczyła najbliższego sąsiada Polski, czyli Niemiec, bądź Austrii (gdzie postanowienia z Schengen weszły z pewnym opóźnieniem), ale odleglejszych społeczeństw i gospodarek, które otworzyły swoje rynki pracy jako pierwsze po naszej akcesji (a zatem Wielkiej Brytanii i Republiki Irlandii).

Najbardziej współczesne zestawienia badawcze CBOS-u pozwalają rzucić pewne światło na skłonność do podjęcia pracy za granica a deklarowana skłonnością do określonych zachowań na rodzimym rynku pracy (osób deklarujących pozostawanie bezrobotnymi) z perspektywy bardziej współczesnej uwzględniającej moment akcesji.

Wyjazd za granicę w poszukiwaniu pracy akceptowany jest wśród osób bezrobotnych na poziomie od ok. $25 \%$ do ok. $50 \%$ na przestrzeni bez mała 10 lat. Okres największego nasilenia migracji to również wyraźny spadek zainteresowania wyjazdami zarobkowymi za granice (w okresie nasilenia bezrobocia było to ponad $50 \%$, a w 2008 - jedynie $26 \%$, a zatem o połowę mniej). Można zapewne pisać o pewnym „wysycaniu” tej strategii radzenia sobie z brakiem pracy. Co ważne, deklaratywna skłonność do wyjazdu (jako strategii poszukiwania pracy) systematycznie wzrasta $\mathrm{w}$ ostatnich latach, by przyrosnąc o ok. $10 \%$ na przestrzeni ostatnich lat (do 38\%). Zmiana była również (jak dotąd) diachroniczna, gdy analizujemy dynamikę zjawiska narastania kryzysu na europejskich rynkach pracy, który uderzył w 2008 i 2009 r. Poprawa sytuacji gospodarczej zmniejsza zatem skłonność do mobilności, obniża również wskaźniki migracyjne.

Zapewne bezrobocie nie wyczerpuje wszystkich „czynników wypychajacych”. Jest ich znacznie więcej niż tylko uwarunkowania rynku pracy, obejmują one choćby zagadnienia ładu społecznego, np. rozległość i efektywność transferów socjalnych, jakość instytucji edukacyjnych i oferty skierowanej do młodych, zagadnienia polityki zdrowotnej, zabezpieczeń emerytalnych, warunków pracy, czynniki kulturowe (w tym stosunku obywateli do swojej wspólnoty narodowej i akceptacji jej opuszczania) czy kwestie dziedziczenia wzorów migracyjnych. Oczywiście określenie, który z nich jest najważniejszy, jest trudne bez osobnych analiz i badań społecznych uwzględniających trudno uchwytną badawczo grupę emigrantów (trudność ta dotyczy zwłaszcza reprezentatywnych badań). W tym momencie ważniejsze od bardziej jednoznacznych i naukowych odpowiedzi na pytanie o główne motywy migracji wydaje się dostrzeżenie bardziej generalnych i utrzymujacych się znacznych różnic rozwojowych zarówno w obrębie Europy Środkowej i Wschodniej, jak i w relacjach pomiędzy krajami naszego regionu a bardziej rozwiniętymi krajami zachodu i północy naszego kontynentu.

(lata 2002-2004). Te wysokie i najwyższe w okresie po 1989 r. wartości wskaźnika bezrobocia (w zaproponowanej analizie mierzone istnieniem doświadczeń pozostawania bez pracy) przypadaja na marzec $2003 \mathrm{r}$. 
Jakkolwiek usytuowanie Polski na mapie rozwojowej kontynentu na przestrzeni ostatnich lat poprawiło się o kilkanaście procent (powołuję się na wskaźnik poziomu siły nabywczej na podstawie danych Eurostatu), to różnica do średniej unijnej nadal pozostaje ok. 40\%, a proporcje różnic pomiędzy poszczególnymi krajami naszego regionu nie uległy radykalnym przewartościowaniom. Przywołam tylko przykład Czech, gdzie poziom wyjściowy jest o 20\% wyższy niż w przypadku Polski (czyli ok. 70\% średniej dla UE), a obserwowana zmiana jest relatywnie mała - zamknęła się we wzroście 7\%. Można zatem dostrzec bariery liniowej poprawy poziomu życia, co również może podważyć optymistyczna, „wykładniczą” wizję doganiania czy wyrównywania szans w wyobrażalnych ramach czasowych.

Można, w moim przekonaniu, zasadnie pisać o relatywnie stałym poziomie czynników wypychających, który nie ulegnie znaczącemu osłabieniu, zakładając - rzecz jasna - brak jakichś radykalnych wydarzeń czy katastrof na skalę regionalną. Warto, akceptując to ogólne spostrzeżenie, zauważyć zdecydowanie wyższą dynamikę rozwojową naszych północnych postsowieckich sąsiadów (Litwy, Łotwy i Estonii), którzy w relatywnie krótkim czasie byli w stanie zrównać poziom życia z tym statystycznie rejestrowanym w naszym kraju (przypomnijmy, że zmiany demokratyczne i urynkawiające rozpoczęły się tam nieco później). W przypadku dwóch pierwszych krajów (Litwy i Łotwy) niejako jednocześnie z poprawianiem się siły nabywczej obserwujemy jednak intensywny, zdecydowanie zresztą bardziej dynamiczny niż w Polsce emigracyjny odpływ siły roboczej (będę omawiał to zjawisko na przykładzie emigracji z Łotwy). Jego źródła są oczywiście interesujące z punktu widzenia wyjaśniania intensywności zjawisk migracyjnych w naszym regionie i może on stanowić interesujący materiał porównawczy. Poza przykładami wzmożonej mobilności są również takie, które łączy z nami postkomunistyczny rodowód, a wskaźniki bilansu migracji wskazują na względną stabilność, tak jest w przypadku przywołanych Czech, ale także przeżywających do niedawna kłopoty gospodarcze Węgier. Można zatem obserwować sytuacje, gdy względnie porównywalne różnice poziomu życia mierzone siłą nabywczą nie generują znaczących odpływów siły roboczej. Pozwala to podjąć analizę czynników, które określiłem jako „indywidualne”, choć jednocześnie ich „indywidualistyczny” charakter nie jest zupełnie oczywisty.

Przez „czynniki indywidualne” będę rozumiał czynniki, które w większym zakresie dotyczą indywidualnych motywacji i strategii migranta. W tym sensie pozostają bliższe „czynnikom przyciagającym”, opisywanym w literaturze dotyczacej migracji (ang. pull factors), czyli zbiorom motywatorów decydujących o tym, które z miejsc np. z krajów-gospodarek uznaje się za najbardziej optymalny cel migracji z punktu widzenia określonych kryteriów, gdy podejmuje się decyzje na temat kierunku wyjazdu. 


\section{Diagram 1}

Ilustracja specyfiki wpływu czynników wypychających (ang. push factors) i czynników przyciagających (ang. pull factors) indywidualnych - spotykana w literaturze poświęconej migracji

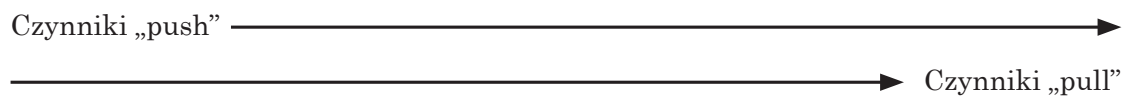

„Zwrot” obydwu tendencji jest taki sam, co sugeruje, że są one w stanie ze sobą „współdziałać”, tworząc warunki wzmagania zjawiska migracji (dodatnie sprzężenie zwrotne). Można jednak logicznie wyobrazić sobie inne konfiguracje czynników, co pozwala na poznawcze wykorzystanie koncepcji push-pull do analiz porównawczych i poszukiwania odpowiedzi na pytanie dotyczące różnic dynamiki migracyjnej w różnych warunkach w różnych społeczeństwach środkowoeuropejskich.

\section{IV. „CZYNNIKI INDYWIDUALNE” A „CZYNNIKI WYPYCHAJĄCE” BĄDŹ STRUKTURALNE}

Rekonceptualizacja czynników „wypychających” i „przyciagających” pozwala na poszerzenie pola interpretacji zjawiska migracji. Tak jak w pierwszym przypadku głównym kontekstem analitycznym będą: dany poziom życia, sytuacja na danym rynku pracy, z którego wywodzą się migranci itd. ${ }^{20}$ W drugim chodzi raczej, używając języka ekonomicznego, o „stronę popytową" rozpatrywana jako pula możliwych wyborów, przy założeniu, że praca jest „dobrem elastycznym”, czyli że rzeczywiście istnieje możliwość dokonania wyboru, dysponujemy wiedzą o określonych opcjach, koszt podjęcia decyzji nie jest skrajnie wysoki. Motywacje emigranta dotycza zatem w większym stopniu poprawy „mojego losu”, w opozycji do kontekstu społecznego, który emigrując, też można „wybrać”. Przyjmuję, że wybór ten jest w drugim przypadku bardziej indywidualny (co dla socjologa jest dosyć kłopotliwym kontekstem analitycznym), stosuje się kryteria właściwe dla partykularnego podmiotu, na tyle oczywiście, na ile tego rodzaju wybory mogą nie zapośredniczyć kontekstu grupowego czy strukturalnego.

Co warto podkreślić, w przyjętym kształcie obydwa typy motywacji migracyjnych są nie tylko odrębnej natury, ale w istocie dotyczą również innych segmentów struktury społecznej. Co z kolei może wynikać z interpretacji specyfiki społecznej refleksyjności i konstatacji dotyczących barier nie tyle przemieszczania się, ile raczej znajdowania „odpowiedniej” pozycji społecznej w nowym miejscu (czy jak chcieliby ekonomiści: barier dostępu do rynku pracy). Rozróżnienie to jest jednak nadal dosyć formalne. By przejść od wizji statycznych

${ }^{20}$ Wynikaja z tego pewnego typu motywacje zmiany miejsca zamieszkania, które obejmuja oczekiwania dotyczące np. jakości i poziomu życia, jakości i poziomu zaspokojenia określonych potrzeb itd. 
relacji do opisu dynamiki społecznej (migracja zdecydowanie należy do pola badawczego socjologii zmiany społecznej), wypada rozważyć możliwe korelacje pomiędzy obydwoma aspektami z punktu widzenia uwarunkowań decyzji migracyjnej. Gdy posłużymy się perspektywą instytucjonalna, pojawią się co najmniej dwie logiczne możliwości, które warto rozważyć. Pierwsza wskazywałaby, że czynniki wypychające moga być neutralizowane przez określone inne strukturalne uwarunkowania, co sprawia, że migracja w większym zakresie nie występuje. Takim czynnikiem mogą być określone aspekty minimalizowania nierówności społecznych, redystrybucji, czy szerzej: mechanizmy dystrybucji własności ${ }^{21}$.

W zaproponowanym opracowaniu skłonny jestem wskazać na stabilizujące bądź „przyciagające” funkcje czynników indywidualnych, obejmujących poza różnicami społecznymi czy statusowymi także pewne rozpowszechnione strategie i wyobrażenia, co pozwala odwołać się do klasycznego kontekstu instytucjonalnego zaczerpniętego z tzw. starego instytucjonalizmu. Tutaj wzory instytucjonalne są dziedziczone z pokolenia na pokolenie i genetycznie „niedostosowane” do warunków, jakie wytwarzają stosunki gospodarcze ${ }^{22}$.

Zaproponowane interpretacje przedstawię w formie trzech ogólnych hipotez wypełniajacych logicznie relacje pomiędzy dwoma rodzajami czynników (,wypychajacych” i ,indywidualnych”).

H1. Emigracja wynika z nasilenia ,czynników wypychających". Kontekst indywidualnych decyzji nie wpływa na zjawisko. Taka sytuację można sobie wyobrazić w dwóch co najmniej przypadkach. Pierwszy, to ograniczenie indywidualnej wolności podmiotu przez np. ograniczenia w przyznawaniu paszportów itp. Dobrym przykładem podobnych praktyk może być okres realnego socjalizmu w sytuacji nasilonego konfliktu Wschód-Zachód, w tym np. sytuacja zamknięcia granicy pomiędzy RFN i byłym NRD, bądź też sytuacja „umożliwienia” wyjazdu przy założeniu, że osoby wyjeżdżające nie wrócą (część emigracji lat osiemdziesiątych XX w. z Polski czy też wcześniejsze zjawisko odpływu osób pochodzenia żydowskiego pod koniec lat sześćdziesiątych).

21 Zacytuję tutaj tylko jeden wątek wniosków z przywołanej już pracy M. Nowak, M. Nowosielski (red.), op. cit.: „[...] w krajach postkomunistycznych bardziej aktywna rola państwa w relacji do problemu zatrudnienia, opieki zdrowotnej i opieki zdrowotnej wobec ludzi starszych jest relatywnie powszechnie akceptowana". Z tego punktu widzenia określone braki efektywnych rozwiązań lub wprost błędy w realizowanej polityce mogą prowadzić do napięć społecznych, którym można przypisać role współprzyczyn zjawiska masowej migracji. Innym aspektem podobnego kontekstu analitycznego może być dostrzeżenie rozpowszechnienia Hirshmanowskiej strategii „exit” (rozstania), która wyraźnie zaczyna dominować nad „polityczną” strategią „voice” (krytyka), co z kolei daje np. podstawy do interpretacji dynamiki sfery politycznej ostatnich, co najmniej 10 lat w naszym kraju. Por. M. Nowak, Inequalities and Migration (Mainly on Polish Perspective). Why Do Central and Eastern European Societies Need More Welfare State, w: M. Nowak, M. Nowosielski (red.), op. cit., s. 51.

22 Por. T. Veblen, Teoria klasy próżniaczej, Muza, Warszawa 1998; M. Nowak, Instytucjonalizmu w socjologii i ekonomii. Problem i jego konceptualizacja, WN PWN, Poznań 2009, s. 159. 
Drugi przypadek, choć zapewne mniej jednoznaczny, to aktywna polityka państwa zmierzająca do stabilizowania presji migracyjnej przez system transferów socjalnych i aktywną politykę na rynku pracy itp. W jakimś zakresie przykłady tego rodzaju polityki da się zaobserwować w formułach europejskiego welfare state. Trudno jednak sobie wyobrazić efektywnie działajacy ład społeczny, który charakteryzuje niższy poziom rozwoju z silną ingerencja państwa w gospodarkę i który jednocześnie pozbawiony jest zagrożenia migracyjnego. Doświadczenia środkowoeuropejskie wskazują (mam na myśli przykłady Polski i Węgier początku lat dziewięćdziesiątych), że koszt takiego systemu socjalnego wsparcia silnie obciąża budżety i ogranicza jednocześnie konkurencyjność gospodarek.

H2. Emigracja jest rezultatem współoddziaływania „czynników wypychających" (strukturalnych) i ,indywidualnych". Nasilenie tendencji migracyjnych zależy w tym przypadku nie tyle od nasilenia każdego z tych czynników (poziomu deprywacji czy zakresu wolności), ile z ich wzmacniania się nawzajem. A zatem chodzi o relatywnie wysoki poziom różnic (stałe nasilenie czynników wypychających) w zakresie jakości i poziomu życia w sytuacji np.: 1) częściowej delegitymizacji ładu blokującej możliwości usuwania napięć społecznych legalnymi narzędziami politycznymi (np. buntu realizowanego za pośrednictwem związków zawodowych) lub 2) sytuacji, w której takie usuwanie napięć jest bardzo kosztowne, lub 3) nie znajduje się w dostępnym instrumentarium uczestników życia publicznego. Za przykład może służyć przypadek absolwenta uczelni, który nie jest w stanie znaleźć zatrudnienia w zawodzie na lokalnym rynku pracy bądź oferowane za jego pracę wynagrodzenie jest niewspółmiernie niskie i poszukuje on zatrudnienia wykorzystującego jego kwalifikacje za granica. Z taka sytuacja, moim zdaniem, możemy mieć do czynienia w wybranych przypadkach masowych emigracji z Europy Środkowej i Wschodniej, i to zarówno tych „niepolitycznych” z końca lat osiemdziesiątych, jak i tych $\mathrm{z}$ lat dziewięćdziesiątych XX w. oraz najmłodszej po 2004 r.

H3. Emigracja jest rezultatem nasilenia (specyfiki) „czynników indywidualnych". Czynniki strukturalne nie wywierają poważniejszego wpływu. Taka sytuacja wydaje się typowa dla społeczeństw o wysokim poziomie życia z dobrze rozwiniętymi mechanizmami rynkowymi. Emigracja pojawia się tutaj jako następstwo indywidualnych decyzji typu rynkowego (poszukiwanie lepiej płatnej pracy, pracy w określonym zawodzie czy po prostu oczekiwania zmiany w życiu osobistym). Można również przyjąć, że taki model jest podstawa powstania globalnej siły roboczej, a zatem siły roboczej, która z racji najczęściej unikalnych kwalifikacji w istocie oderwana zostaje od konkretnego miejsca.

By oddać jeszcze precyzyjniej intencje: obydwa „typy” motywacji i typy czynników (wypychajacych i indywidualnych) moga za podstawę brać kwestie „materialne”, różni je jednak zarówno pozycja zawodowa, o jaką toczy się „gra”, jak i podmiotowość aktorów, którzy w pierwszym przypadku (hipoteza 1, dalej: H1) raczej „musza”, w trzecim (hipoteza 3, dalej: H3) raczej „chca” 
zmieniać miejsce zamieszkania bądź pracy. Wynika to z charakteru czynników obydwu rodzajów. Pierwszy dotyczy umownie „warunków wyjściowych”, które można postrzegać jako dane jednostce i względnie niezmienne w określonych warunkach, drugi zaś dotyczy indywidualnej konceptualizacji szans, jakie niesie ze sobą nowe miejsce (por. treść przyp. 4).

$\mathrm{Z}$ tego punktu widzenia możemy pisać również o odrębnej naturze wymagającej odrębnych narzędzi teoretycznych. Pierwszy (H1) z nich w jakimś sensie zostaje nierozerwalnie powiąany z dysfunkcjonalnością czy „anomicznością" ładu społecznego. Drugi (H2) stanowiłby konsekwencję naturalnych zróżnicowań/nierówności społecznych budujących możliwą korelację pomiędzy „przymusem” a „wyborem”. Ten trzeci (H3) zaś wynikałby z prawa do „rynkowego” wyboru i indywidualnej refleksyjności, które są np. elementami późnonowoczesnej konstrukcji „elastycznego pracownika” na zintegrowanym rynku pracy. Możemy zatem pisać (akceptując zaproponowane rozróżnienie motywów) np. o odrębnym statusie poszukującego środków na zakup mieszkania w Polsce absolwenta wyższej uczelni z Poznania wyjeżdżającego „na zmywak" do Londynu (H1) oraz specjalisty z Londynu poszukującego możliwości samorealizacji w innym miejscu pracy (H3), w innym kraju (H3). Dodam, że obydwaj mogą mieć porównywalny status edukacyjny, a nawet porównywalne kwalifikacje. Możemy tu analogicznie dostrzec pozycje długotrwale bezrobotnych, którzy nie podejmuja prób wyjazdu i np. korzystają ze świadczeń socjalnych gwarantowanych przez państwo (podobnie H1) oraz kontekstu indywidualnej decyzji migracji opartej na motywacjach (nie)politycznego buntu i podejmowania ryzyka Mertonowskiej innowacji (H2).

Nieco inaczej ten obraz kształtuje się, gdy weźmiemy pod uwagę zróżnicowanie typów migracji. Emigracja osiedleńcza odpowiadałaby zdecydowanie hipotezom H1 i H2; formy elastycznych wyjazdów krótkoterminowych czy też czasowy wyjazd zarobkowy końca lat osiemdziesiątych i dziewięćdziesiątych XX w. bardziej odpowiadałyby hipotezie H1. Wyjazd kontraktowy związany np. z praca w globalnej korporacji odpowiadałby hipotezie H3 itd.

Wypada jednak unikać jednoznacznie modernizacyjnego odczytania różnicy pomiędzy obrazem szkicowanym przez hipotezy H1 i H3, tym bardziej że ewolucja czynników rozwojowych w Europie Środkowej, przynajmniej na przestrzeni ostatnich 25 lat, nie daje po temu zadowalających uzasadnień.

\section{MOTYWY EMIGRACJI W KONTEKŚCIE „CZYNNIKÓW INDYWIDUALNYCH”}

Problem motywów mobilności jest kłopotliwym poznawczo zagadnieniem, głównie ze względu na złożenie elementów, które da się określić jako indywidualne, przeciwstawiając je łatwiej identyfikowalnym czynnikom strukturalnym. Rolą socjologa w odniesieniu do tak zróżnicowanych uwarunkowań jest uchwycenie prawidłowości, które mogą prowadzić do uogólnień. Socjologiczne odpowiedzi zapewne ułatwi założenie względnej zgodności doświadczeń wpi- 
sanych we wspólny (lub raczej podobny) los i np. podobne wydarzenia, które potencjalnie definiują tożsamość i podmiotowość generacyjną jednostek ${ }^{23}$.

Problem socjologiczny migracji dotyczy zatem nie tego, co „specyficzne”, ale raczej tego, co typowe i wpisane w losy kohort, logikę procesu uzyskiwania społecznej dojrzałości, ale także starzenia się i typowych dla perspektywy generacyjnej relacji władzy. Ten ostatni element jest szczególnie interesujacy w odniesieniu do doświadczeń Europy Środkowej i Wschodniej, gdzie z reguły znaczące zmiany w sferze gospodarczej (związane często z pogorszeniem poziomu życia) towarzyszyły zmianie rezimu socjalnego i specyfiki sprawowania władzy. Zmiany te, przebiegające w kierunku demokratyzacji, zawierały w sobie równolegle tendencje do deregulacji i liberalizacji, które z kolei dynamizowały nierówności społeczne już wcześniej istniejące. Emigracja w (przyjętym rozumieniu zjawiska) stanowiła, co sugeruję, odpowiedź na te zmiany. Nieprzypadkowo więc, z racji swej egzystencjalnej specyfiki: zerwania bezpośredniego związku z jednym miejscem (mniej lub bardziej traumatycznego dla jednostki) i wchodzenia w nowe środowiska i nowe warunki, niesie ona w sobie skumulowanie napięć ${ }^{24}$ i ,selekcjonuje” jednostki ze względu na ich skłonność do ponoszenia ryzyka. $Z$ tego powodu emigracja jest bardziej domeną młodych osób, ale oczywiście nie tylko.

Przy okazji rekonstrukcji głównych tez badania Ewy Jaźwińskiej, Wojciecha Łukowskiego i Marka Okólskiego warto wskazać na wyróżniające się motywy ekonomiczne, a precyzyjniej - te związane z różnicami siły nabywczej i strategiami szybkiego (i znaczącego) poprawienia jakości życia własnego i rodziny w miejscu pierwotnego zamieszkania. Co ważne, przywoływane argumentacje nie odwoływały się (jak można sądzić na podstawie lektury opracowania raportowego) do wizji awansu społecznego, co w przypadku migracji poakcesyjnej miało większe znaczenie. Znacznie rzadziej pojawiały się tutaj wątki „modernizacji” (w bardzo szerokim sensie), jaką miała nieść ze sobą emigracja postransformacyjna. Podobnie słaby był związek pomiędzy strategiami emigracyjnymi a zaangażowaniem w sferę publiczna. Emigracja była z tego punktu widzenia formą milczącego „głosowania nogami” w opozycji do bardziej publicznego odrzucenia czy rezygnacji. Nie zerwała jednocześnie zwiąków z pierwotnym miejscem zamieszkania, ale budowała nowe typy relacji niejako poza kontekstem lokalnym (przestrzennie) i w związku z kontekstem lokalnym (tożsamościowo i kulturowo).

Zapewne charakter wniosków, które proponują autorzy, w istotnej mierze warunkowany jest samym doborem respondentów i miejscami badania (analizowano gospodarstwa domowe w Łubnianach, Mońkach, Namysłowie,

${ }^{23}$ Tak jest zapewne w przypadku zjawisk mobilności inspirowanych kryzysem gospodarczym drugiej połowy lat 80 . XX w., tak jest w związku z otwarciem bezwizowego ruchu turystycznego na początku lat 90 . XX w. oraz późniejszym (o kilkanaście lat) otwarciem granic związanym z ustaleniami z Schengen. Dobry przegląd takich motywacji migracyjnych zawierają analizy z lat 90. - E. Jaźwińskiej, W. Łukowskiego i M. Okólskiego, Przyczyny emigracji z Polski. Wstepne wyniki badań $w$ czterech regionach za pomoca podejścia etnosondażowego, Seria: Prace Migracyjne 7, 1997.

${ }^{24}$ Które dobrze ilustrują wypowiedzi zawarte w opracowaniu I. Kasane - w dalszej części artykułu. Por. I. Kasane, Emigration as a Strategy of Everyday Politics: The Case of Latvian Labour Emigration in Ireland, w: M. Nowak, M. Nowosielski (red.), op. cit. 
Nowym Targu, Perlejewie i Warszawie), jednocześnie jednak może wskazywać na zróżnicowany charakter postrzegania migracji w różnych segmentach struktury społecznej. Można również uznać, że zestawienie motywacji migracyjnych lat osiemdziesiątych i dziewięćdziesiątych XX w. oraz emigracji współczesnej ujawnia zmiany postrzegania wyjazdów i wartości, jakie przypisuje się emigracji.

W jakimś sensie podkreślają to wyniki badań emigrantów do Wielkiej Brytanii, która nastapiła po 2004 r., zrealizowanych przez Macieja Milewskiego i Joannę Ruszczak-Żbikowską. Respondenci, zapytani wprost o przyczyny migracji ( $\mathrm{N}=1593$, na podstawie ankiety internetowej), wskazywali na źródła ekonomiczne (63\% wskazań), podobnie zresztą jak w przypadku wcześniej przywołanych analiz, dalej były to (z podobnym poziomem deklaracji akceptujących) wskazania na zamiar nauki, pogłębienia znajomości języka (46\% wskazań) oraz sytuacja polityczno-ekonomiczna w Polsce (44\%). Argumentacja bezpośrednio nawiązująca do łatwiejszego znalezienia pracy znalazła się na kolejnym miejscu z mniej więcej jedną trzecią wskazań twierdzących (36\%). Autorzy cytują zresztą wypowiedź jednego z ankietowanych: przyczyna migracji były „lepsze zarobki [w Wielkiej Brytanii], zła polityka gospodarcza w Polsce, brak możliwości rozwoju zawodowego, lepsza perspektywa na dalsze życie". Ci sami autorzy wskazali na podstawie analizy czynnikowej na trzy typy motywacji rekonstruowanych w wypowiedziach respondentów. Określili je jako: „konieczność życiowa”, „lepsze perspektywy życiowe” oraz „nowe doświadczenia”. Pierwsza i druga z motywacji okazały się skądinąd najbardziej rozpowszechnione, wiążąc w sobie zestawienie możliwości, jakie się ma w nowym miejscu, i szans, jakie dane sa w Polsce i kraju docelowym. Sugeruje to specyficzne powiązania argumentów strukturalnych, które wprost opisywane sa jako wypychające, z „indywidualnymi”, postrzeganymi jako racjonalizowany (w tym przypadku post factum) kontekst indywidualnej decyzji $(\mathrm{H} 1)^{25}$.

Bardzo szczególnym przypadkiem strategii indywidualnej inspirowanej strukturalnie może być „strategia migracyjna ludzi zbędnych” 26 . W badaniach z lat dziewięćdziesiątych XX w. ilustruje ona formy wyjazdu i zawiera w sobie motywy zerwania czy nowego początku. Przytoczę cytat zawierający wypowiedź ojca, nieco przypominajacca kontekst analizy, jaki przywołam w odniesieniu do doświadczeń emigracji z Łotwy:

\footnotetext{
Moja córka, jak skończyła szkołę w roku 1985, starała się o pracę w swoim zawodzie (.) Nie mogła dostać pracy jako laborantka. Po próbach przyjęcia się w innych specjalnościach, w różnych zakładach była zniechęcona. Trafiały się prace o bardzo niskich zarobkach. [...] To był rok 1988 i pojechała. Tylko wspominała: Jak mi się spodoba, zorientuję się, to może zostanę. Ale nic nie mogę powiedzieć, bo jeszcze tam nie byłam. No i stało się. Po tygodniu czasu inni z Wiednia wrócili i zawiadomili nas, że córka została, postanowiła zostać. Widocznie zdecydowała się, zorientowała się, że tam będzie miała lepszą przyszłość $(\mathrm{N} 1)^{27}$.
}

Istota motywacji do wyjazdu może być tutaj co najmniej dwojakiego rodzaju: 1) córka respondenta nie wierzyła w to, że system w ogóle da jej szansę realizacji celów życiowych (całościowa ocena); 2) córka respondenta nie była

${ }^{25}$ M. Milewski, J. Ruszczak-Żbikowska, op. cit., s. 11.

${ }^{26}$ E. Jaźwiński, W. Łukowski, M. Okólski, op. cit., s. 69.

${ }^{27}$ Ibidem. 
gotowa na długotrwałą inwestycję - oczekiwała radykalnej poprawy własnego losu (indywidualne oczekiwania). Pierwsza z motywacji wskazywałaby jednoznacznie na hipotezę H1, druga zaś sugerowałaby modalność hipotezy H2. Pojawia się jednak pytanie o pozycję społeczna jaką chce (chciała) i ewentualnie uzyskała respondentka. Takiej odpowiedzi na podstawie materiału z badania jednak nie otrzymujemy.

Motyw braku perspektyw i poszukiwania tych perspektyw w strategiach emigracyjnych pojawia się zresztą w opracowaniu Jaźwińskiej, Łukowskiego i Okólskiego częściej. Warto, jak sądzę, temu typowi motywacji i temu kontekstowi migracyjnemu ${ }^{28}$ poświęcić nieco więcej uwagi w bliskim nam kontekście północno-wschodniej Europy.

\section{PRZYKLAD EMIGRACJI LOTEWSKIEJ}

Nawiązuję tutaj do intrygującego opracowania Ivety Kasane, socjolożki łotewskiej opisującej zjawisko emigracji Łotyszy do Republiki Irlandii. Zjawisko migracji wywołało na Łotwie, podobnie zreszta jak w Polsce, ożywiona dyskusję. Tam jednak, jak sugeruje autorka, jedną z ważnych osi dyskusji było prawo do opuszczania kraju i wskazanie na pewnego rodzaju zdradę, jakiej dopuszczają się migranci w stosunku do swojej wspólnoty ${ }^{29}$.

Zjawisko emigracji towarzyszyło rzeczywistości łotewskiej od momentu odzyskanie niepodległości (maj 1990), co autorka próbuje opisać, nawiązując do zmian politycznych, precyzyjniej zaś - jako opór wobec rządu („resistance to particular forms of government"); emigrację tę oceniano z punktu widzenia dwóch procesów o politycznym i ekonomicznym charakterze reorientujących Łotwę, raz - w kierunku nacjonalizmu, dwa - reform ekonomicznych realizowanych, skądinąd podobnie jak w Polsce, w oparciu o porozumienie z Międzynarodowym Funduszem Walutowym. Kontekstem, na który autorka zwraca szczególną uwagę, była „niska skuteczność wydatków publicznych” oraz - jak pisze - „dominujący dyskurs etnopolityki w łotewskim parlamencie i brak dyskusji na temat praw socjalnych (social welfare)" pozostajaccy, jej zdaniem, $\mathrm{w}$ związku z narastaniem tendencji migracyjnych.

Przywołam cytat z wywiadu, jaki autorka zrealizowała z emigrantem:

Jestem ze wsi i tutaj jest ciagle bieda. Być może niecałkowita, ale ciagle ludzie kupują rzeczy używane (second hand) i najtańsze jedzenie, które przekroczyło datę przydatności do spożycia. I ludzie to robia. Mówię tobie [uwaga skierowana do osoby przeprowadzającej wywiad] to jest bieda! Ryga to jest kompletnie inny świat $[\mathrm{DPNK}]^{30}$.

${ }^{28}$ Przypomnę, mam na myśli wskazaniu na czynniki strukturalne jako przesłankę poszukiwania uzasadnień realizacji strategii indywidualnej.

${ }^{29}$ I. Kesane, op. cit.

${ }^{30}$ Ibidem, s. 141. 


\section{Oraz inny:}

Teraz ja mam wszystko, ja mam wolny czas, ja mam Internet - dostrzegam prawdziwą twarz Łotwy. Nie łotewską twarz (Łotwa sama jest czymś przyjaznym), ale rząd, politykę, rozwój, szczerze mówiąc, lepiej jest obserwować z zewnątrz [SPDG] ${ }^{31}$.

Emigracja - wedle tej autorki - była zatem działaniem w pewien sposób strategicznym: wyraźnie zorientowanym na poprawę bytu materialnego (trudno dowodzić, że było inaczej), ale jednocześnie motywem działania była indywidualna podmiotowość (lub oczekiwanie podmiotowości). Jak sama stwierdza w podsumowaniu: ,[...] decyzje migracyjne zawieraja w sobie zagadnienia socjalne, ekonomiczne i polityczne" ${ }^{32}$.

Przywołanych przez autorkę przykładów wypowiedzi nie da się sprowadzić jedynie do czynników strukturalnych (bieda), podobnie zresztą jak rozpatrywanie migracji tylko w odniesieniu do czynników indywidualnych (odrzucenia polityki rządu, czy dążenia do samorealizacji) okazałoby się poznawczo nieskuteczne. Zasadne wydaje się więc rozpatrywanie przykładu łotewskiego (tak jak go opisuje Kasane), ale również pewnej części polskiej emigracji, jako wariantu pozytywnej weryfikacji hipotezy 1 i 2 (H1 i H2), a precyzyjniej - ewolucyjnego kontinuum łączącego obydwa typy.

\section{PRZESTRZENNE (REGIONALNE) UWARUNKOWANIA MIGRACJI - ZNACZENIE CZYNNIKÓW INDYWIDUALNYCH}

Analizowane przestrzennie zróżnicowania zjawisk migracyjnych wskazuja na bardzo znaczace dysproporcje. Sugeruje to powiązanie natężenia mobilności z uwarunkowaniami na poszczególnych rynkach pracy, co powinno dać się zaobserwować w analizie danych dotyczących bezrobocia.

1. Na podstawie analizy przywołanych danych można stwierdzić, że w $2004 \mathrm{r}$. poziom bezrobocia w najbardziej nim dotkniętym województwie (warmińsko-mazurskim) był dwa razy większy niż w najmniej nim dotkniętym województwie (mazowieckim), proporcje udziału w ogólnym odpływie sił roboczej nie były jednak adekwatne (np. dwukrotnie wyższe), a najbardziej dotknięte bezrobociem województwo zajmowało jednocześnie przedostatnie miejsce w rankingu zestawiajacym poziomy odpływu siły roboczej. Zatem teza, że nadmiar „niewykorzystanej” siły roboczej (mierzonej poziomem bezrobocia) implikuje bezpośrednio odpływ siły roboczej, nie znajduje pełnego oparcia w przedstawionych danych, choć sam relatywnie niewielki związek da się zarejestrować (Pearson: 0,36) ${ }^{33}$.

31 Ibidem, s. 143

32 Ibidem, s. 147.

33 By to spostrzeżenie poprawnie zweryfikować, sprawdziłem, czy istnieje związek pomiędzy udziałem poszczególnych województw w ogólnym bezrobociu (rejestrowanym na podstawie danych GUS-u) a ekwiwalentnym odpływem siły roboczej z poszczególnych województw. 
2. Tendencja ta, co warto podkreślić, przeczy również przekonaniu, że lepsze proporcjonalnie warunki życia „immunizują zjawiska wypływu siły roboczej. Pozwala to na bardziej śmiałe poszukiwanie czynników, które „mediują", bądź wprost na wskazanie na nieadekwatność myślenia o bezpośrednim związku pomiędzy mobilnością a sytuacją na rynku pracy $\mathrm{w}$ odniesienia do Polski, która charakteryzuje niezwykłe istotne zróżnicowanie pod względem rozwojowym oraz pewien zakres napięć społecznych generowanych przez sam ład społeczny.

\section{Tabela 1}

Bezrobocie, zjawiska migracyjne - w podziale na województwa

\begin{tabular}{|l|c|r|r|c|c|c|c|}
\hline Województwo & SB 2004* & \multicolumn{1}{c|}{ A } & \multicolumn{1}{c|}{ B } & WSM>2004 & WSM<2007 & A 2005 & B 2005 \\
\hline Mazowieckie & 15,9 & 4,7 & 6,6 & $-0,63$ & $-0,49$ & 5,74 & 0,23 \\
\hline Małopolskie & 16,4 & 15,1 & 10,6 & 0,88 & 0,29 & 8,74 & 1,40 \\
\hline Wielkopolskie & 17,6 & 4,3 & 5,7 & $-0,52$ & $-0,35$ & 6,56 & $-2,01$ \\
\hline Podlaskie & 17,6 & 7,7 & 5,5 & 1,61 & 0,87 & 5,53 & $-0,25$ \\
\hline Śląskie & 18,2 & 5,4 & 6,7 & $-0,58$ & $-0,47$ & 10,29 & $-1,96$ \\
\hline Lubelskie & 19,3 & 8,9 & 8,2 & 0,44 & 0,32 & 11,45 & $-2,08$ \\
\hline Podkarpackie & 20,8 & 14,2 & 13,2 & 1,69 & 1,48 & 6,69 & 1,27 \\
\hline Łódzkie & 21,2 & 3,6 & 4,3 & $-0,53$ & $-0,43$ & 7,76 & $-1,09$ \\
\hline Opolskie & 21,8 & 6,8 & 3,1 & 1,63 & 0,22 & 3,99 & 0,62 \\
\hline Świętokrzyskie & 22,6 & 4,7 & 5,6 & 0,27 & 0,53 & 2,61 & $-0,53$ \\
\hline Pomorskie & 23,0 & 3,9 & 4,3 & $-0,26$ & $-0,17$ & 6,01 & 1,57 \\
\hline Dolnośląskie & 24,3 & 7,3 & 13,2 & $-0,04$ & 0,21 & 7,31 & 0,55 \\
\hline $\begin{array}{l}\text { Kujawsko-po- } \\
\text { morskie }\end{array}$ & 25,3 & 4,2 & 6,3 & $-0,23$ & 0,16 & 6,02 & 0,25 \\
\hline Lubuskie & 28,2 & 2,2 & 2,4 & $-0,28$ & $-0,17$ & 5,35 & 1,60 \\
\hline $\begin{array}{l}\text { Zachodniopomor- } \\
\text { skie }\end{array}$ & 29,1 & 3,7 & 4,7 & $-0,12$ & 0,12 & 2,55 & $-0,20$ \\
\hline $\begin{array}{l}\text { Warmińsko- } \\
\text {-mazurskie }\end{array}$ & 30,9 & 3,3 & 3,4 & $-0,08$ & $-0,06$ & 3,4 & 0,86 \\
\hline W sumie*: & & $100^{*}$ & $100^{*}$ & & & $100^{*}$ & \\
\hline
\end{tabular}

* Stopa bezrobocia na podstawie danych Głównego Urzędu Statystycznego z 2004 r.

A - udział w całkowitym odpływie ludności do $2004 \mathrm{r}$.

B - udział w całkowitym odpływie ludności w latach 2004-2007.

WSM>2004 - informują o różnicach między udziałem emigrantów z danego województwa w odpływie ludności a udziałem mieszkańców z tegoż województwa w ogóle ludności kraju.

WSM<2007 - informują o różnicach między udziałem emigrantów z danego województwa w odpływie ludności a udziałem mieszkańców z tegoż województwa w ogóle ludności kraju.

A 2005 - udział w całkowitym bezrobociu w procentach.

B 2005 - analogicznie do WSM informuje o różnicach między udziałem osób bezrobotnych z danego województwa a udziałem mieszkańców z tegoż województwa w ogóle ludności kraju.

Źródło: dane dotyczące poziomu migracji opublikowane w dokumencie: M. Mioduszewska, Najnowsze migracje z Polski w świetle danych Badania Aktywności Ekonomicznej Ludności, CMR Working Papers, Seria: Prace Migracyjne 39/94, 2008. 
3. Istnienie związku pomiędzy różnicami między udziałem emigrantów z danego województwa w odpływie ludności a udziałem mieszkańców z tegoż województwa w ogóle ludności kraju (dla okresu poprzedzającego akcesję do struktur UE i następującej po tym okresie) potwierdza poziom korelacji Pearsona (korelacja Pearsona: 0,77). Sugeruje pokrywanie się regionów, z których emigrowali Polacy, i generalnie - przedłużenie trendów odpływu siły roboczej. Zmiany w zakresie liczebności emigracji nie są bardzo znaczące i dotycza odpływu w przypadku najliczniejszego województwa mazowieckiego i wyraźnego spadku mobilności w przypadku województwa małopolskiego. Migracja spadła w przypadku jednego z najmniejszych województw: opolskiego i znowu znacznie wzrosła w przypadku dolnośląskiego. Można zapewne wnioskować o przesuwaniu się w latach po naszej akcesji do struktur UE fali migracyjnej w kierunku zamożniejszych województw, co jednak nie podważa wskazanej już tendencji do przestrzennej ciagłości zachowań migracyjnych przed rokiem 2004 i później.

Migracji zatem nie da się interpretować w kontekście prostych związków przyczynowych, choć jednocześnie poziom bezrobocia nie pozostaje bez wpływu na jej wielkość. Wydaje się, że wskazane zestawienie hipotez H1 i H2, $\mathrm{w}$ kategoriach swoistego kontinuum daje w tym zakresie sensowne podstawy interpretacyjne, warte dalszego wykorzystania ${ }^{34}$.

\section{WNIOSKI WRAZ ZE SZKICEM REKOMENDACJI}

Formułujac wnioski z analiz i interpretacji zaproponowanych w artykule, warto postawić pytanie o ocenę zjawiska. Odpowiedź, jeżeli nie ma być ideologicznym opowiedzeniem się za „ekonomistycznym” bądź „tradycyjnie społecznym" (wspólnotowo-narodowym) punktem widzenia, musi odwoływać się do dwóch typów argumentacji. Pierwszy dotyczy wpływu mobilności na lokalny kontekst życia społecznego i wspólnotowego. Z reguły bezdyskusyjnie przyjmuje się, że ten wpływ jest pozytywny, zapewne warto tym zagadnieniem zająć się bez uproszczeń i opierać się na konkretnych studiach przypadków, czy np. analizach biograficznych.

Drugi dotyczy makrospołecznych konsekwencji migracji, które oddziałuja w różnych perspektywach czasowych. Na wstępie wskazałem na potencjalne negatywne konsekwencje wynikajace z bardziej generalnych trendów starzenia się społeczeństw europejskich i wprost trendów depopulacyjnych w naszym regionie. Podam przykłady Litwy i Polski, gdzie na podstawie projekcji w latach 2035 i 2060 przewidywany jest znaczący spadek liczby ludności ${ }^{35}$.

${ }^{34}$ Brak bezpośrednich, łatwo identyfikowalnych wniosków oraz nacisk ideologicznych interpretacji to z liberalnej, to z etatystycznej strony powinny implikować pogłębioną refleksję badawczą co do przyczyn i specyfiki migracji.

${ }^{35}$ Dla naszego północno-wschodniego sąsiada o 10,6 i 19,6\% (czyli o jedną piąta), a dla naszego kraju - o 3,4 i 14,3\% (czyli jedną szóstą populacji). Powołuję się tutaj na prognozy przygotowywane przez badaczy Eurostatu. Por. „Eurostat News Releas” 80/2011, 8 June 2011, http://epp. eurostat.ec.europa.eu/cache/ITY_PUBLIC/3-08062011-BP/EN/3-08062011-BP-EN.PDF. 
Dostrzeżenie tych zjawisk, nie dość wyraźne dzisiaj, powinno uruchomić dyskusję na temat „polityki mobilnościowej” oraz dotychczas nie szacowanych kosztów otwartego rynku pracy w strukturach UE.

Można w tym kontekście sformułować obawy, czy projektu modernizacyjnego, w jaki wpisuje się idea zjednoczonej Europy (łączącej znacząco biedniejsze kraje wschodu i południa kontynentu z bogatszymi i nieco inaczej ulokowanymi w ramach systemu światowego krajami) nie osłabiają masowe zjawiska migracyjne. Poważnym zagrożeniem mogą być np. rosnące zadłużenie i słabość systemów emerytalnych obciążających budżety państw biedniejszych, charakteryzujacych się dużym odpływem siły roboczej (jak choćby Bułgaria, Litwa, Łotwa, Polska, Rumunia). Ograniczają one np. możliwości aktywnej polityki rozwojowej zorientowanej (zgodnie skądinąd z misją UE) na wyrównywanie szans i możliwości obywateli. Nie postuluję tu jednak działań, które miałby administracyjnie ograniczać mobilność, chodzi raczej o oddziaływanie na zaproponowane w artykule „czynniki indywidualne”, które musi zostać poprzedzone przez badania przyczyn emigracji wykraczające poza wizje „samoczynnego" redukowania „swego rodzaju nadwyżki demograficzno-społecznej” (cytat z jednej ze znaczacych publikacji na temat współczesnej migracji) bądź analizy przygodności ludzkich losów. Takie badania winny wskazać specyfikę poszczególnych motywacji oraz odpowiedzieć na pytanie o rodzaj migracji, który ma dla nas sens rozwojowy ze względu na pożądane społecznie wartości. Kluczem do takiej interpretacji mogą być analizy uwarunkowań przestrzennych, pozwalające zdefiniować potrzeby mobilnościowe i możliwe kierunki ruchliwości z obszarów dotkniętych np. wysokim poziomem bezrobocia czy bezrobociem strukturalnym do miejsc, gdzie to bezrobocie mieści się w ramach parametrów „pełnego zatrudnienia” (czyli niewiele przekracza 4\%, a tak jest przecież w kilku największych polskich miastach). Emigracja międzynarodowa jest tutaj zaledwie jedna z opcji i - w moim przekonaniu - jedną z bardziej ryzykownych zarówno egzystencjalnie dla samych migrantów, jak i z punktu widzenia systemowych uwarunkowań w ramach europejskiego rynku pracy (np. grozi w Europie Zachodniej spadkiem poziomu płac i poziomu życia, w Europie Środkowej zaś - np. wzrostem tzw. bańki na rynku nieruchomości). Dla tych, którzy zdecydowali się „zostać”, oznacza finansowanie rosnących kosztów podstawowych świadczeń zbiorowych i kosztów funkcjonowania sfery publicznej, opłacanych przecież z indywidualnych podatków. Problem ten należy, jak sądzę, podjąć w sposób pragmatyczny, rozpoczynając od szacunków kosztów i ewentualnych korzyści, uwzględniając konkretne uwarunkowania społeczne, a ich podstawą może być zaproponowany kontekst teoretyczny.

dr Marek Nowak

Uniwersytet im. Adama Mickiewicza w Poznaniu marek.nowak@amu.edu.pl 


\title{
POLISH MIGRATION: MOTIVES FOR THE MOBILITY, ITS DYNAMICS AND A PROPOSAL OF SOCIOLOGICAL RECONCEPTUALISATION
}

\author{
Summary
}

The article recapitulates basic information on contemporary Polish international migrations. First, consecutive waves of migration of the 1980 are presented, followed by later developments of the late 1980s and 1990s of the twentieth century, up to the beginning of the twenty first century being a result of the political consequences of the enlargement of the EU (namely Poland's joining the Europen Union and the subsequent Schengen agreement in 2004). After that certain "push factors' occurring in Central and Eastern Europe are being described and the term: 'individual factors' is introduced. The main goal of the analysis presented in the article was to propose a possible strategy for answering questions regarding different intensiveness of the emigration from Central and Eastern European countries, bearing in mind that the quality of life in individual states - sources of that emigration - were comparable.

In the analysis, available data from the Eurostat, government statistics, and sociological surveys were used. 
Copyright of Journal of Law, Economics and Sociology is the property of Faculty of Law and Administration of Adam Mickiewicz University in Poznan and its content may not be copied or emailed to multiple sites or posted to a listserv without the copyright holder's express written permission. However, users may print, download, or email articles for individual use.

Właścicielem praw autorskich do „Ruchu Prawniczego, Ekonomicznego i Socjologicznego” jest Wydział Prawa i Administracji Uniwersytetu im. Adama Mickiewicza w Poznaniu. Zawartość czasopisma nie może być kopiowana, przesyłana do innych stron internetowych bądź zamieszczana na blogach bez pisemnej zgody wydawcy. Niemniej artykuły można drukować, kopiować lub przesyłać w formie elektronicznej na własny użytek. 